A N N A L E S

UNIVERSITATIS MARIAE CURIE-SKŁODOWSKA LUBLIN - POLONIA

VOL. LXV, z. 2

SECTIO F

2010

\title{
MONIKA KROGULSKA-KRYSIAK
}

Instytut Historii UWM

\section{Problem białoruski na łamach „Prawdy”, „Świata” \\ $i$ "Tygodnika Ilustrowanego" w poczatkach XX wieku}

Белорусская проблема на страницах „Prawdy”, „Świata”

и „Tygodnika Ilustrowanego” в начале XX века

Przedmiotem rozważań jest analiza artykułów dotyczących zagadnień białoruskich, które pojawiły się na łamach warszawskiej prasy na początku XX wieku. Nie ulega wątpliwości, że problem białoruskiego odrodzenia kulturalnonarodowego największym zainteresowaniem cieszył się na łamach prasy wileńskiej. Wilno, miasto, w którym działała młoda białoruska inteligencja, było miejscem, gdzie wiedza o rozwijającym się białoruskim ruchu narodowym i jego aspiracjach była o wiele większa niż gdzie indziej. Wybór prasy ukazującej się w Warszawie wiąże się z próbą odpowiedzi na pytanie, jak kwestia białoruskiego odrodzenia narodowego była postrzegana w społeczeństwie polskim żyjącym poza terenem działania i obecności tego ruchu. Skoncentruję się zatem na sposobie przedstawiania białoruskiego ruchu narodowego na łamach wybranych warszawskich tygodników oraz ocenie możliwości jego dalszego rozwoju na podstawie publikacji zamieszczonych na łamach takich tygodników, jak: „Prawda”, „Tygodnik Ilustrowany” i „Świat”.

Artykuły i korespondencje dotyczące Białorusi i Białorusinów ukazywały się w nich, począwszy od roku 1905, kiedy to zniesienie cenzury prewencyjnej spowodowało pojawienie się w nich odważniejszego spojrzenia na tematykę społeczną i narodową. Konieczna wydaje się w tym miejscu krótka charakterystyka wyżej wymienionych tytułów prasowych. Pozwoli to na wskazanie cha- 
rakteru czasopism oraz wyjaśni postrzeganie i interpretację kwestii białoruskiej na ich łamach.

Po raz pierwszy „Prawda” ukazała się na warszawskim rynku prasowym w 1881 roku i była głównym czasopismem pozytywistów warszawskich. Pierwszym redaktorem był Aleksander Świętochowski, czołowy przedstawiciel polskiego liberalizmu, założyciel i lider Związku Postępowo-Demokratycznego. „Prawda” istniała do 1915 roku. Był to tygodnik o charakterze społeczno-politycznym i kulturalnym, ale zamieszczano w nim także artykuły o treści gospodarczej oraz teksty o charakterze popularnonaukowym. „Prawda” nigdy nie reprezentowała określonej partii politycznej, niemniej jednak skupili się wokół niej publicyści będący zwolennikami reform o charakterze demokratycznym, walczący z zacofaniem kulturalnym, nietolerancją i fanatyzmem.

„Tygodnik Ilustrowany” istniał od 1859 roku i ukazywał się aż do wybuchu II wojny światowej. W interesującym nas okresie pismo przeżywało rozkwit, ukazywały się w nim artykuły m.in. o treści społecznej, politycznej, historycznej. W tym też czasie tygodnik współpracował z takimi postaciami, jak: Czesław Jankowski ${ }^{1}$, Stefan Gorski², Henryk Mościcki ${ }^{3}$, które swoimi korespondencjami wprowadzały czytelnika w zawiłości sytuacji narodowościowej na obszarze tzw. Litwy historycznej, w tym także w tematykę białoruską.

Kolejnym periodykiem, który na swoich łamach podejmował zagadnienia białoruskiego ruchu narodowego, był wychodzący pod redakcją dziennikarza Stefana Krzywoszewskiego tygodnik „Świat”. Pismo zajmowało się przede wszystkim przedstawianiem bieżących wydarzeń kulturalnych i politycznych.

Należy podkreślić, że żadne $\mathrm{z}$ wymienionych czasopism nie było organem określonej grupy politycznej, stąd nie reprezentowało poglądów właściwych poszczególnym partiom. Zarówno „Prawda”, „Tygodnik Ilustrowany”, jak i „Świat” pełniły rolę informacyjno-edukacyjną poprzez zamieszczanie artykułów o treści społeczno-kulturowej oraz materiałów o tematyce historycznej i gospodarczej.

Zagadnieniem rozpatrywanym przez publicystów na łamach wymienionych tygodników była kwestia narodzin, kształtowania się oraz aktywności ruchu białoruskiego. Wojciech Baranowski (dziennikarz, redaktor naczelny „Kuriera

${ }^{1}$ Czesław Jankowski (1857-1929) - poeta, krytyk literacki, dziennikarz, długoletni współpracownik „Kraju” (w latach 1902-1904 sekretarz redakcji w zastępstwie Erazma Piltza). Redaktor „Kuriera Litewskiego” w latach 1905-1907.

${ }^{2}$ Stefan Gorski (1882-1941) - publicysta, redaktor i wydawca. Od 1906 roku kierownik działu aktualności w „Tygodniku Ilustrowanym”.

${ }^{3}$ Henryk Mościcki (1881-1952) - historyk, publicysta, współpracował m.in. z „Tygodnikiem Ilustrowanym” i „Kwartalnikiem Historycznym”. 
Litewskiego" w latach 1907-1910) w artykule Budzący się naród, który ukazał się w 1911 roku w „Świecie”, upatrywał genezę ruchu odrodzenia Białorusinów w wydarzeniach 1905 roku w Rosji. Twierdził, że zapoczątkowany wtedy ruch społeczny sprawił, iż „chłop białoruski przypomniał sobie, że nie jest Rosjaninem"', a dzięki podjętej wówczas pracy kulturalnej ruch ten przekształcił się w narodowy. Podobny pogląd wyraził Michał Römer ${ }^{5}$ na łamach „Prawdy”. W obszernym artykule Zagadnienia narodowe białoruskie. (Szkic publicystyczno-etnograficzny) zaznaczył, że przez rewolucję w 1905 roku „fala odrodzenia białoruskiego rozlała się [...] szerzej”'. Umożliwiona została, choć w niewielkim jeszcze stopniu, działalność wydawnicza, oświatowa i polityczna. Michał Römer podkreślał jednak, że Białorusini nie są jeszcze gotowi do samodzielnego bytu w sensie społecznym i politycznym, gdyż istnieje ludność białoruska, ale nie białoruski naród, który dopiero powoli zaczyna się formować7. Podobną uwagę, również na łamach „Prawdy”, zaprezentował publicysta podpisujący się jako P. Zubowicz. W artykule Białorusini (nota bene bardzo inspirowanym już wcześniej przytaczanym artykułem M. Römera) stwierdził, iż „lud białoruski nie posiada zindywidualizowanej świadomości narodowej ani odporności na wpływy obce”. Równocześnie opisywał proces białorutenizacji Litwinów na terenie guberni wileńskiej, podkreślając jednak, że „Litwin zbiałorutenizowany łatwo ulega wpływom polskim”. Również Czesław Jankowski, w artykule w „Tygodniku Ilustrowanym", zaznaczał, że pełna świadomość narodowa wśród Białorusinów jeszcze się nie obudziła ${ }^{10}$. Przyczyn „opóźnienia” ruchu białoruskiego, w porównaniu do ruchu litewskiego, estońskiego czy łotewskiego, upatrywano przede wszystkim w ograniczeniu białoruskiej grupy etnicznej do warstwy chłopskiej ${ }^{11}$ (jak również w wyjątkowo niekorzystnym położeniu na styku kultury polskiej i rosyjskiej). M. Römer stwierdził, że „rdzeń ludności białoruskiej, ludność wło-

${ }^{4}$ W. Baranowski, Budzący się naród, „Świat”, nr 34 z 26 VIII 1911, s. 1.

${ }^{5}$ Michał Römer (1880-1945) - prawnik, uczony, publicysta, działacz społeczno-polityczny, historyk litewskiego odrodzenia narodowego, jeden z wybitnych „krajowców” wileńskich. Autor książki Litwa. Studium o odrodzeniu narodu litewskiego (wyd. we Lwowie w 1908 roku).

${ }^{6}$ M. Römer, Zagadnienia narodowe białoruskie (Szkic publicystyczno-etnograficzny), „Prawda”, nr 36 z 7 IX 1907, s. 424.

${ }^{7}$ Idem, Zagadnienia narodowe, „Prawda”, nr 34 z 24 VIII 1907, s. 400.

${ }^{8}$ P. Zubowicz, Białorusini, „Prawda”, nr 26 z 26 VI 1909, s. 6.

${ }^{9}$ Ibid., s. 7.

${ }^{10}$ Cz. Jankowski, Na Litwie i Białejrusi, „Tygodnik Ilustrowany”, nr 22 z 29 V 1909, s. 432.

${ }^{11}$ Zob. M. Römer, Zagadnienia narodowe, „Prawda”, nr 32 z 10 VIII 1907, s. 375; Cz. Jankowski, Na Litwie, „Tygodnik Ilustrowany”, nr 22 z 29 V 1909, s. 432; W. B. [Wojciech Baranowski], Ruch białoruski, „Tygodnik Ilustrowany”, nr 37 z 14 IX 1912, s. 768. 
ściańska, nie jest jednolita pod względem kulturalnym, wyznaniowym, a nawet etnograficznym"12.

Kolejnymi więc elementami charakterystyki białoruskiego ruchu była próba przedstawienia liczebności i rozmieszczenia terytorialnego Białorusinów oraz ich przynależności religijnej. Wspomniany już Wojciech Baranowski w artykule Ruch białoruski, zamieszczonym w „Tygodniku Ilustrowanym”, na podstawie badań profesora J. Karskiego szacował liczbę ludności białoruskiej na osiem milionów, przy czym najliczniej miała ona występować w guberniach mińskiej, wileńskiej i grodzieńskiej ${ }^{13}$. Bardziej precyzyjny opis rozmieszczenia Białorusinów przedstawił M. Römer. Podzielił Białoruś na dwie części - prawosławną (wschodnią) i katolicką (zachodnią), którą nazywał także Rusią Litewską. Dokładnie scharakteryzował sytuację narodowościową i wyznaniową w guberniach: mohylewskiej, witebskiej, mińskiej, grodzieńskiej, wileńskiej, kowieńskiej, które uważał za tereny zamieszkałe także przez ludność białoruską. Zdaniem M. Römera miejscem, gdzie w największym stopniu zachowały się kultura ludowa i język białoruski, była Mińszczyzna, którą określił „właściwym ośrodkiem i jądrem Białej Rusi"14.

Niezwykle istotna wśród publicystów była kwestia wyznania Białorusinów. Znaczna przewaga wyznania prawosławnego (zdaniem W. Baranowskiego prawosławni stanowili $2 / 3$ ogółu ludności białoruskiej ${ }^{15}$ ) ułatwiała rusyfikację. M. Römer podkreślał, że „cerkiew, duchowieństwo prawosławne i szkoła są na Białej Rusi narzędziami bezwzględnej rusyfikacji”"16. Sprzyjało temu w pewnej mierze także pokrewieństwo obyczajowe i językowe $\mathrm{z}$ Rosjanami. Białorusini wyznania katolickiego zamieszkiwali głównie w guberniach wileńskiej, grodzieńskiej i mińskiej ${ }^{17}$. Obok chłopów byli to przedstawiciele drobnej szlachty, którzy nie różnili się trybem życia i pracy od ludności włościańskiej. Co istotne, M. Römer nie obawiał się wykorzystywania religii katolickiej do celów polonizacji Białorusinów. Wręcz przeciwnie, widział we „wpływie katolicko-polskim [...] skuteczny równoważnik wpływów rosyjskich”18. W 1906 roku w „Tygodniku Ilustrowanym” ukazał się tekst Stefana Gorskiego, w którym autor relacjonuje audiencję u biskupa wileńskiego Edwarda Roppa. W rozmowie z bi-

\footnotetext{
${ }^{12}$ M. Römer, Zagadnienia narodowe, „Prawda”, nr 32 z 10 VIII 1907, s. 375.

${ }^{13}$ W. B. [Wojciech Baranowski], Ruch białoruski, „Tygodnik Ilustrowany”, nr 37 z 14 IX 1912, s. 768.

${ }^{14}$ M. Römer, Zagadnienia narodowe, „Prawda”, nr 33 z 17 VIII 1907, s. 387.

${ }^{15}$ W. B. [Wojciech Baranowski], Ruch białoruski, „Tygodnik Ilustrowany”, nr 37 z 14 IX 1912, s. 768.

${ }^{16}$ M. Römer, Zagadnienia narodowe, „Prawda”, nr 32 z 10 VIII 1907, s. 375.

${ }^{17}$ W. B. [Wojciech Baranowski], Ruch białoruski, „Tygodnik Ilustrowany”, nr 37 z 14 IX 1912, s. 768.

${ }^{18}$ M. Römer, Zagadnienia narodowe, „Prawda”, nr 32 z 10 VIII 1907, s. 375.
} 
skupem publicysta poruszył również temat wygłaszania kazań w językach narodowych, w tym m.in. w języku białoruskim. Otrzymał odpowiedź, iż „zaprowadzone zostaną kazania w ich [Białorusinów - M. K-K.] języku, kiedy wymagania narodowe ludu staną się dojrzałymi"19. Biskup, nastawiony zresztą przychylnie do ruchu białoruskiego, wyraził także pogląd, że Białorusini wyznania katolickiego będą ciążyć ku polskiej kulturze i trzeba ten wpływ wykorzystać w walce $\mathrm{z}$ rusyfikacją ${ }^{20}$. W podobnym tonie wypowiedział się biskup E. Ropp w liście wysłanym do redakcji wileńskiego „Kuriera Litewskiego”21.

Uwagę warszawskiej publicystyki szczególnie zajmowała kwestia polonizacji i rusyfikacji Białorusinów. Michał Römer w przytaczanym wcześniej szkicu publicystyczno-etnograficznym poświęcił wiele miejsca temu zagadnieniu. Białoruś nazwał "klasycznym wzorem wiązadła między dwiema kulturami”22, punktem, gdzie „zbiegały się i krzyżowały polskie i rosyjskie wpływy”23. Zaznaczał, że przeważająca część rosyjskiej opinii publicznej nie wie o odrębności Białorusi i uważa ją za część Rosji właściwej. Optymistycznie jednak zakładał, iż polityka rosyjska, która doprowadziła do znacznego zruszczenia ludności na wschodnich terenach białoruskich, wkrótce przybierze inny wymiar i kulturalne pierwiastki rosyjskie, wpływające na rozwój ludności krajowej, przestaną być zjawiskiem bezwzględnie szkodliwym ${ }^{24}$. Obawiał się jednak tego, czy Białorusini zdołają odpowiednio wykorzystać wpływy kultury rosyjskiej. Oddziaływanie polskie nie było, zdaniem M. Römera, dla ruchu białoruskiego niebezpieczne, gdyż proces uważał za zakończony. Stanowisko społeczeństwa polskiego wobec Białorusi nazwał polityką „wolnych drzwi”, czyli „wolnego oddziaływania wszelkich wpływów"25. Rolą Polaków było zaakceptowanie i wsparcie odrębności Białorusinów. Było to stanowisko zgodne z założeniami idei krajowej, którą M. Römer reprezentował. Podkreślał ten fakt również Wojciech Baranowski, pisząc: „krajowe żywioły polskie widzą w emancypacji Białej Rusi [...] zjawisko

${ }^{19}$ ST. GR. [Stefan Gorski], Dążenia narodowe a Kościól katolicki na Litwie. Audiencja u J. E. biskupa Roppa, „Tygodnik Ilustrowany”, nr 36 z 8 IX 1906, s. 705.

${ }^{20}$ Ibidem.

${ }^{21}$ Zob. E. Ropp, W sprawie języka białoruskiego. List do redakcji, „Kurier Litewski”, nr 135 z 18 VI (1 VII) 1906. Szerzej o stosunku biskupa E. Roppa do problemów narodowościowych diecezji zob. R. Jurkowski, Edward Ropp jako biskup wileński 1903-1907 (W 50-tą rocznicę śmierci), „Studia Teologiczne” 1990, t. VIII, s. 205-280.

${ }^{22}$ M. Römer, Zagadnienia narodowe, „Prawda”, nr 34 z 24 VIII 1907, s. 400.

${ }^{23}$ Ibidem.

${ }^{24}$ Ibidem.

${ }^{25}$ Idem, Zagadnienia narodowe, „Prawda”, nr 35 z 31 VIII 1907, s. 413. 
ze wszech miar pożądane"26. Jego zdaniem polonizacja groziła Białorusinom w niewielkim stopniu, Polacy bowiem nie mieli tendencji do narzucania swej kultury. Zwracał jednak uwage na fatalne w skutkach działania władz rosyjskich, m.in. wydawanie w Wilnie gazety „Biełorusskaja Źizń”, przeznaczonej dla Białorusinów, a drukowanej po rosyjsku. Negatywnie oceniał postępowanie redakcji „Naszej Niwy”, która wprowadziła druk pisma grażdanką ${ }^{27}$. Z kolei Czesław Jankowski w artykule $\mathrm{Na}$ Litwie i Białejrusi zauważył, że prawdopodobnie ruch białoruski ma szansę otrzymać poparcie władz rosyjskich i odrębność narodowa Białorusinów zostanie uznana przez Rosję. Miało to się odbyć kosztem społeczeństwa polskiego i w konsekwencji ze stratą dla samych Białorusinów, którzy nie byliby w stanie obronić się przed wpływami kultury rosyjskiej ${ }^{28}$.

Wymienieni autorzy w swoich tekstach starali się przedstawić także działania inteligencji białoruskiej na rzecz uświadamiania narodowego włościan. Podkreślano zwłaszcza wydawanie periodyków „Nasza Dola” i „Nasza Niwa”, elementarza białoruskiego, czytanek dla dzieci, dzieł Franciszka Bohuszewicza, Wincentego Dunin-Marcinkiewicza, Janka Kupały i Jakuba Kołasa. Wojciech Baranowski zaznaczył, że Białorusini to lud „rozkochany w pieśni”"29, i wychwalał działające w Wilnie białoruskie „kółko muzyczno-dramatyczne”, które kultywowało pieśń białoruską ${ }^{30}$. Pisano o działalności Ihnata Bujnickiego i Wacława Iwanowskiego, o Białoruskim Związku Włościańskim i Związku Białoruskich Nauczycieli Ludowych. Kwestia badań naukowych nad językiem białoruskim w zasadzie nie była poruszana. Jedynie Michał Römer przy okazji charakterystyki piśmiennictwa białoruskiego nadmienił, że jego największą trudnością jest ustalenie ,języka i pisowni wobec wielkiej rozbieżności gwar ludowych na terytorium Białej Rusi i wobec bliskiego pokrewieństwa języka białoruskiego z rosyjskim i polskim"31.

Ciekawym zabiegiem stosowanym przez publicystów polskich było porównanie białoruskiego i litewskiego ruchu narodowego. O tym ostatnim na łamach prasy warszawskiej pisano głównie w kontekście trwającego sporu polsko-litewskiego, w tym podnoszenia przez litewskich działaczy narodowych postulatu autonomii Litwy. Należy podkreślić, że w odróżnieniu od ruchu litewskiego do ruchu białoruskiego odnoszono się pozytywnie. Wojciech Baranowski pisał, iż:

\footnotetext{
${ }^{26}$ W. B. [Wojciech Baranowski], Ruch białoruski, „Tygodnik Ilustrowany”, nr 38 z 21 IX 1912, s. 791.

${ }^{27}$ Ibidem.

${ }^{28}$ Cz. Jankowski, Na Litwie, „Tygodnik Ilustrowany”, nr 22 z 29 V 1909, s. 432-433.

${ }^{29}$ W. B. [Wojciech Baranowski], Ruch białoruski, „Tygodnik Ilustrowany”, nr 37 z 14 IX 1912, s. 768.

${ }^{30}$ W. Baranowski, Budzący się naród, „Świat”, nr 34 z 26 VIII 1911, s. 3.

${ }^{31}$ M. Römer, Zagadnienia narodowe, „Prawda”, nr 36 z 7 IX 1907, s. 424.
} 
„[c]harakterystyczną jest rzeczą, że nawet w owych najostrzejszych momentach ruch białoruski ludowy nie odznaczał się tą zaciekłością, jaka cechowała w podobnych chwilach Litwinów" ${ }^{\prime 32}$. W podobnym tonie wyraził się o ruchu białoruskim znany adwokat wileński Tadeusz Wróblewski w rozmowie z Henrykiem Mościckim, historykiem i publicystą „Tygodnika Ilustrowanego”. Wnioskował, że białoruski ruch odrodzeniowy, przynajmniej w najbliższym czasie, nie przybierze tej formy co litewski ${ }^{33}$. Jego zdaniem ruch białoruski był jeszcze zbyt słaby, by stawiać podobne jak Litwini żądania. Sądził również, że wydarzenia 1905 roku w Rosji spowodowały złagodzenie „wystąpień nacjonalistycznych” i „walk separatystycznych” wśród Białorusinów ${ }^{34}$. Bardziej sceptyczny był Czesław Jankowski, twierdząc, że nacjonalizm białoruski po prostu się jeszcze nie obudził i spór polsko-białoruski wkrótce się rozpocznie ${ }^{35}$. Natomiast Michał Römer ruch litewski stawiał za wzór dla Białorusinów. Szczególnie podkreślał aktywność polityczną Litwinów, zwłaszcza ich dążenia do autonomii. Nieskuteczne zaangażowanie polityczne, zdaniem M. Römera, źle świadczyło o dojrzałości kulturalnej i politycznej Białorusinów ${ }^{36}$. Należy w tym miejscu zaznaczyć, że w omawianym czasie kwestia białoruskiego odrodzenia narodowego była poruszana znacznie rzadziej niż litewska. Przyczyn należy doszukiwać się także w fakcie, że Białorusini i Litwini znajdowali się wtedy w różnym stadium rozwoju narodowego. W 1905 roku ruch litewski wchodził już w tzw. fazę masową, kończącą proces narodotwórczy. Natomiast ruch białoruski po rewolucji 1905 roku dopiero rozpoczynał agitację wśród ludności ${ }^{37}$. Trudno wobec tego przedstawić konkretne dane statystyczne, jednak na podstawie analizy artykułów z samego „Tygodnika Ilustrowanego" z lat 1905-1914 można stwierdzić, że stosunek ilościowy ukazanych publikacji na tematy białoruskie i litewskie wynosił jak jeden do trzech ${ }^{38}$.

Reasumując, należy stwierdzić, że problematyka białoruska nie gościła zbyt często na łamach popularnych warszawskich periodyków, dlatego też dla mieszkańców Królestwa Polskiego białoruski ruch narodowy był zagadnieniem prawie nieznanym. W porównaniu do prasy wileńskiej tematyka białoruska w pra-

\footnotetext{
${ }^{32}$ W. B. [Wojciech Baranowski], Ruch białoruski, „Tygodnik Ilustrowany”, nr 37 z 14 IX 1912, s. 768.

${ }^{33} \mathrm{H}$. Mościcki, Era konstytucyjna na Litwie (z rozmów i wrażeń), „Tygodnik Ilustrowany”, nr 5 z 10 II 1906, s. 95.

${ }^{34} \mathrm{Ibidem}$.

${ }^{35}$ Cz. Jankowski, Na Litwie i Białejrusi, „Tygodnik Ilustrowany”, nr 37 z 14 IX 1912, s. 432.

${ }^{36}$ M. Römer, Zagadnienia narodowe, „Prawda”, nr 36 z 7 IX 1907, s. 424.

${ }^{37}$ Zob. M. Hroch, Małe narody Europy, Warszawa 2003, s. 8, 9, 35-40.

${ }^{38}$ Por.: M. Krogulska-Krysiak, Litwa na łamach „Tygodnika Ilustrowanego" w latach 1905-1914, „Meritum” 2009, t. 1, s. 115-123.
} 
sie warszawskiej poruszana była incydentalnie, a zadaniem przytoczonych artykułów było przede wszystkim dostarczenie czytelnikowi informacji o sytuacji narodowej na Białorusi. Wysokim poziomem merytorycznym odznaczał się omawiany cykl artykułów autorstwa Michała Römera, opublikowany na łamach „Prawdy”. Nie ulega wątpliwości, że to właśnie ten tygodnik reprezentował najdojrzalsze podejście do zagadnień białoruskich. Wynikało to z faktu, iż „Świat” i „Tygodnik Ilustrowany” były pismami o profilu bardziej popularnym, o „żejszej” wymowie, skierowanym do szerokiego kręgu odbiorców. Analiza publikacji w omawianych trzech tygodnikach pokazywała ich życzliwe nastawienie do białoruskiego odrodzenia. Doceniano walkę o własną tożsamość, tym bardziej że przeciwstawiano się wielkoruskiej koncepcji Białorusinów jako „zachodnich Rosjan”, propagowanej przez nacjonalistów rosyjskich. Białorusini nie atakowali przy tym zaciekle wpływów polskich, co czynili np. Litwini. Jednak, jak już wcześniej podkreślałam, wybrane przeze mnie trzy tygodniki nie reprezentowały skrajnych poglądów politycznych. Stąd nie należy sądzić, że przedstawiany na łamach tych wybranych warszawskich czasopism przychylny stosunek do narodowego odrodzenia białoruskiego był reprezentatywny dla całej prasy warszawskiej.

\section{PEЗЮME}

Целью статьи является анализ текстов касающихся вопросов Беларуси, которые появились на страницах варшавских журналов в начале XX века. На основе публикаций помещённых на страницах таких еженедельников как „Prawda”, „Tygodnik Ilustrowany” и „Świat” был показанный способ представления белорусского национального движения, а также оценка возможности его дальнейшего развития.

Выбор варшавской печати связанный с попыткой ответа на вопрос: Как проблема беларусского национального возрождения была воспринимана в польском обществе живущем вне территории действования и присутствии этого движения? Вопросами рассматриванными публицистами на страницах вычисленных еженедельников являлся между другими вопрос формирования и активности белорусского движения, а также попытка представления количественного состава и территориального размещения белорусов и их религиозной принадлежности. 